\title{
OPTIMALISASI PORTOFOLIO SAHAM-SAHAM LQ-45 DENGAN MENGGUNAKAN CAPITAL ASSET PRICING MODEL
}

\author{
M Iqbal $^{1}$, Arnah Ritonga $^{2}$ \\ ${ }^{1,2}$ FMIPA Universitas Negeri Medan \\ e-mail : mhmdiqbaltjg@gmail.com
}

\begin{abstract}
ABSTRAK
Tujuan dari penelitian ini adalah untuk memilih dan membentuk sebuah portofolio optimal dari aset-aset berisiko (saham) pada Indeks Liquiditas 45 (LQ-45) dengan menggunakan Capital Asset Pricing Model (CAPM). Sebanyak 45 saham di LQ-45 yang diperoleh dari www.finance.yahoo.com kemudian diseleksi untuk didapatkan lima saham terbaik dengan kriteria returnpositif, beta saham agresif, saham undervalued, dan koefisien variasi positif terkecil. Dengan empat kategori sebelumnya kemudian diperoleh lima saham terbaik yaitu saham Unilever Indonesia Tbk. (UNVR), saham Bank Negara Indonesia (Persero) Tbk. (BBNI), saham HM Sampoerna Tbk. (HMSP), saham Adaro Energy Tbk. (ADRO), dan saham Indocement Tunggal Prakasa Tbk. (INTP). Kriteria portofolio optimal pada penelitian ini adalah portofolio optimal berdasarkan Model Markowitz dengan preferensi return dan risiko dari saham-saham individual, bukan salah satu di antara keduanya. Pembentukan portofolio optimal termasuk menghitung varian, kovarian, dan bobot masing-masing saham, serta return dan risiko portofolio yang dibantu dengan Microsoft Excel Solver add-ins. Fungsi objektif dari optimalisasi ini adalah meminimumkan varian dari portofolio (atau standar deviasi portofolio) sehingga diperoleh output yaitu bobot kelima saham dalam portofolio optimal. Dari penelitian ini diperoleh sebuah portofolio optimal dengan kombinasi dari kelima saham unggul dengan bobot berturut-turut $65.4 \%, 0.0 \%, 20.6 \%, 14.0 \%$, dan 0.0\%. Return dan risiko portofolio optimal tersebut berturut-turut $2.4408 \%$ dan $3.7072 \%$.
\end{abstract}

Kata Kunci: CAPM, LQ-45, Portofolio Optimal, Model Markowitz

\begin{abstract}
The purpose of this research is to select and to form an optimal portfolio from risky assets (stocks) listed in Indeks Liquiditas 45 (LQ-45) using Capital Asset Pricing Model (CAPM). There are 45 stocks listed in LQ-45 which obtained from www.finance.yahoo.com to be selected aiming to choose five best stocks categorized by positive return stocks, aggressive beta stocks, undervalued stocks, and stocks with least positive coefficient of variation. Using four categorizes mentioned before, the five best stocks are stock of Unilever Indonesia Tbk. (UNVR), Bank Negara Indonesia (Persero) Tbk. (BBNI), HM Sampoerna Tbk. (HMSP), Adaro Energy Tbk. (ADRO), and Indocement Tunggal Prakasa Tbk. (INTP). The optimal portfolio's criteria in this research is based on Markowitz Model using return and risk preferences of the individual stocks. The forming of the optimal portfolio includes calculating variances, covariances, and weights of stocks, and also return and risk of the portfolio utilizing Microsoft Excel Solver add-ins software. The objective function of the optimalization is minimizing the variance of the portofolio (or the deviation standard of the portfolio) such that generated the weights of the five stocks as the outputs of the minimization. Therefore, there is a combination of the stocks forming an optimal portfolio that is including $65.4 \%$ of UNVR,
\end{abstract}


KARISMATIKA

VOL. 4 NO. 1 APRIL 2018

p-ISSN : $2443-0366$

e-ISSN : 2528 -- 0279

$0.0 \%$ of BBNI, 20.6\% of HMSP, $14.0 \%$ of ADRO, dan 0.0\% of INTP. The return and the risk of the portfolio are $2.4408 \%$ and $3.7072 \%$.

Keywords : CAPM, LQ-45, OptimalPortofolio,MarkowitzModel

\section{Pendahuluan}

Investasi merupakan suatu kegiatan penempatan dana pada aset produktif dengan harapan mendapatkan pertumbuhan modal (capital growth) dalam jangka waktu tertentu. Orang yang melakukan investasi disebut investor. Umumnya investasi dibedakan menjadi dua, yaitu investasi pada aset-aset finansial (financial assets) dan investasi pada aset-aset riil (real assets). Investasi pada aset-aset finansial di pasar uang, misalnya berupa sertifikat deposito, commercial paper, surat berharga pasar uang, dan lainnya [1].

Salah satu bentuk investasi yang sangat diminati para investor adalah saham yang merupakan instrumen investasi yang memiliki return yang sangat memuaskan. Banyak perusahaan memperjual belikan hak kepemilikannya dalam bentuk saham (stock).

Di Indonesia, ada pasar modal yang hanya memperdagangkan saham-saham aktif yang terdiri dari 45 saham. Pasar modal ini terbentuk karena banyaknya pasar modal yang sebagian sekuritasnya kurang aktif. Pasar modal ini dimulai pada tanggal 13 Juli 1994 dengan nama indeks liquid 45 atau yang lebih dikenal dengan sebutan LQ-45 [2].

Portofolio adalah sekumpulan investasi baik berupa real assets maupun financial assets. Teori portofolio menekankan pada usaha untuk mencari kombinasi investasi optimal yang memberikan tingkat keuntungan (rates of return) maksimal pada suatu tingkat risiko tertentu. Teori portofolio menunjukkan bahwa proses pemilihan investasi adalah tidak hanya sekedar penentuan dan penjumlahan setiap karakteristik sekuritas pembentuk portofolio. Implikasi dari teori ini adalah bahwa investor hendaknya mengkombinasikan aset yang berisiko dalam satu portofolio untuk meminimumkan risiko.

Meskipun teori portofolio yang dikembangkan oleh Harry Markowitz mengatakan bagaimana mengukur risiko tetapi tidak menyebutkan secara spesifik tentang hubungan antarareturn dengan risiko. Baru tujuh tahun kemudian, John Lintner, Jan Moissin, dan William Sharpe mengembangkan Capital Asset Pricing Model (CAPM) yang menunjukkan hubungan antara return dengan risiko . 
CAPM mendasarkan pada asumsi pasar modal yang efisien dengan beberapa tambahan asumsi. Dengan CAPM dapat dijelaskan bahwa return suatu aset adalah fungsi dari risk free rate atau tingkat keuntungan bebas risiko, tingkat keuntungan yang disyaratkan portofolio pasar, dan volatilitas returnaset relatif terhadap returnportofolio pasar yang ditunjukkan oleh koefisienn beta [3].

Capital Asset Pricing Model, sering disebut CAPM, merupakan hasil utama dari ekonomi keuangan modern. CAPM memberikan prediksi yang tepat antara hubungan risiko sebuah aset dengan tingkat harapan pengembalian (expected return). Walaupun CAPM belum dapat dibuktikan secara empiris, CAPM sudah luas digunakan karena CAPM memiliki akurasi yang cukup pada aplikasi-aplikasi penting [4].

Model CAPM merupakan pengembangan teori portofolio yang dikemukakan Markowitz dengan memperkenalkan istilah baru yaitu risiko sistematik (systematic risk) dan risiko spesifik/risiko tidak sistematik (spesific risk/unsystematic risk). Berdasarkan model Markowitz, masing-masing investor diasumsikan akan mendiversifikasikan portofolionya dan memilih portofolio yang optimal atas dasar preferensi investor terhadap return dan risiko pada titik-titik portofolio yang terletak di sepanjang garis portofolio efisien.

Penelitian [5] menemukan bahwa membentuk portofolio optimal dari sahamsaham perbankan yang terdaftar di BEI (Bursa Efek Indonesia) selama periode 2012-2013 menggunakan model Markowitz. Penelitian ini memilih empat saham terbaik yaitu BBCA, BMRI, BBNI, dan BBRI dan dibentuk portofolio optimal dengan menggabungkan dua saham yaitu saham BBCA dan BBNI dengan proporsi optimal masing-masing $72 \%$ dan $28 \%$. Return dan standar deviasi dari portofolio ini secara berurut adalah $0,1 \%$ dan $1,96 \%$. Fitriani (2014) Temuan [5] menyarankan selanjutnya dilakukan penelitian dengan menggunakan model indeks tunggal, CAPM, dan model lainnya.

Penelitian [6] menemukan menganalisis saham-saham sektor perbankan di BEI periode 2009-2011 dengan menggunakan CAPM. Penelitian ini menghasilkan saham BBNI dengan beta 1,93 dan expected return sebesar 5,459\%. Dengan model yang sama, Selanjutnya [10] menganalisis saham-saham di BEI periode 2010-2012 dan menghasilkan dua belas saham efisien (undervalued) dari delapan belas saham sampel penelitian. Kedua penelitian ini berhasil menemukan saham-saham efisien dari sekumpulan saham dengan 
menggunakan CAPM namun tidak membentuk sebuah portofolio optimal yang berisi saham-saham efisien (undervalued).

Penelitian ini akan menggunakan software Microsoft Excel Solver add-ins untuk menghitung bobot (weight) masing-masing saham pada portofolio, varian portofolio, dan return portofolio.

\section{Landasan Teori}

\subsection{Investasi}

Sebuah investasi adalah komitmen pada uang atau sumber lain pada saat ini dengan harapan memperoleh keuntungan pada masa mendatang. Contohnya, seseorang membeli saham dengan mengharapkan penghasilan masa mendatang dari saham tersebut dengan mengorbankan waktu dan uang yang ia simpan sesuai dengan risiko investasi [4].

\subsection{Saham}

Saham adalah surat berharga yang dapat dibeli atau dijual oleh perorangan atau lembaga di pasar tempat surat tersebut diperjualbelikan. Saham merupakan instrumen ekuitas, yaitu tanda penyertaan atau kepemilikan seseorang atau badan usaha dalam suatu perusahaan atau perorangan terbatas [7] .

\subsection{Capital Asset Pricing Model (CAPM)}

CAPM adalah hasil dari studi William F. Sharpe pada tahun 1964 dan juga secara terpisah oleh John Lintner pada tahun 1965. CAPM adalah nama yang diberikan kepada satu kedudukan prinsip yang menerangkan bagaimana para investor berperilaku dalam pasar. Prinsip-prinsip ini merujuk pada pernyataan eksplisit tentang harga keseimbangan, keuntungan, dan risiko untuk sebuah sekuritas [8].

\subsection{Koefisien Beta}

Beta merupakan suatu pengukur volatilitas (fluktuasi dari return-return suatu sekuritas atau portofolio dalam suatu periode waktu tertentu) return suatu sekuritas atau return portofolio terhadap return pasar.

$\beta_{i}=\frac{\operatorname{cov}\left(r_{i}, r_{M}\right)}{\sigma_{M}^{2}}$

Keterangan : 


$$
\begin{aligned}
\beta_{i} & =\text { koefisien beta saham }-\mathrm{i} \\
r_{\mathrm{i}} & =\text { return } \text { saham }-\mathrm{i} \\
r_{M} & =\text { return pasar } \\
\sigma_{M}^{2} & =\text { varian pasar }
\end{aligned}
$$

Sumber : [2]

\subsection{Return}

Return merupakan hasil yang diperoleh dari investasi. Return dapat berupa return realisasi yang sudah terjadi atau return ekspektasi yang belum terjadi tetapi yang diharapkan akan terjadi di masa mendatang.

Asumsi-asumsi yang digunakan di model CAPM adalah sebagai berikut [2] :

1. Semua investor mempunyai cakrawala waktu satu periode yang sama. Investor memaksimumkan kekayaannya dengan memaksimumkan utilitas harapan dalam satu periode waktu yang sama.

2. Semua investor melakukan pengambilan keputusan investasi berdasarkan pertimbangan antara nilai lemph\{return\} ekspektasi dan deviasi standar lemph\{return $\}$ dari portofolionya.

3. Semua investor mempunyai harapan yang seragam (homogeneousexpectation) terhadap faktor-faktor input yang digunakan untuk keputusan portofolio. Faktorfaktor inputyang digunakan adalah expected return, varian dari return, dan kovarian antara return sekuritas. Asumsi ini mempunyai implikasi bahwa dengan harga-harga sekuritas dan tingkat bunga bebas risiko tertentu dan dengan menggunakaninput portofolio yang sama, maka setiap investor akan menghasilkan efficient frontier (kumpulan portofolio efisien)yang sama pula.

4. Semua investor dapat meminjamkan sejumlah dananya (lending) atau memijam (borrowing) sejumlah dana dengan jumlah yang tidak terbatas pada tingkat suku bunga bebas risiko.

5. Penjualan pendek (short sale) diizinkan. Investor individual dapat melakukan short sale berapapun yang dikehendaki.

6. Semua aktiva dapat dipecah-pecah menjadi bagian yang lebih kecil dengan tidak terbatas. Ini berarti bahwa dengan nilai yang terkecilpun investor dapat melakukan investasi dan melakukan transaksi penjualan dan pembelian aktiva setiap saat dengan harga yang berlaku. 
7. Semua aktiva dapat dipasarkan secara likuid sempurna. Semua aktiva dapat dijual dan dibeli di pasar dengan cepat (likuid) dengan harga yang berlaku.

8. Tidak ada biaya transaksi. Penjualan atau pembelian aktiva tidak dikenai biaya transaksi.

9. Tidak terjadi inflasi.

10. Tidak ada pajak pendapatan pribadi. Karena tidak ada pajak pribadi, maka investor mempunyai pilihan yang sama untuk mendapatkan dividen (keuntungan yang dibayarkan pada pemegang saham) atau capital gain (keuntungan modal).

11. Investor adalah penerima harga (price-takers). Investor individual tidak dapat mempengaruhi harga dari suatu aktiva dengan kegiatan membeli dan menjual aktiva tersebut. Investor secara keseluruhan bukan secara individual menentukan harga dari aktiva.

12. Pasar modal dalam keadaan ekuilibrium (seimbang).

\subsection{Risiko}

Risiko didefinisikan sebagai variabilitas (ukuran keberagaman) return terhadap return yang diharapkan. Penyimpangan standar atau standar deviasi merupakan pengukuran yang digunakan untuk mengukur risiko. Risiko juga dapat dinyatakan dalam bentuk kuadrat dari standar deviasi atau varian [2].

Sharpe mendefinisikan risiko sistematik (systematic risk) sebagai ukuran dari variabilitas aset yang dapat disimbolkan dalam sebuah faktor umum. Risiko sitematik adalah hasil dari keadaan pasar dan ekonomi secara umum yang tidak dapat didiversifikasi sedangkan ukuran variabilitas aset yang dapat didiversifikasi (diversifiable) sebagai risiko non-sistematik (nonsystematic risk) [9].

\subsection{Aset Bebas Risiko (Risk Free Rate)}

Aset bebas risiko merupakan suku bunga pada suatu investasi yang tidak mengandung risiko dimana di dalamnya sudah terkandung faktor inflasi. Biasanya berupa suku bunga atas instrumen yang digunakan oleh Bank Sentral untuk mengatur kebijakan moneter, seperti di Indonesia adalah suku bunga Sertifikat Bank Indonesia (SBI) [7]. 


\subsection{Portofolio Optimal Model Markowitz}

Portofolio optimal berdasarkan model Markowitz menggunakan konsep meminimalkan fungsi objektif yaitu fungsi risiko portofolio berdasarkan metode Markowitz.

Minimumkan

$\operatorname{var}(P)=\sum_{i=1}^{n} w_{i}^{2} \cdot \sigma_{i}^{2}+\sum_{i=1}^{n} \sum_{j=1}^{n} w_{i} \cdot w_{j} \cdot \operatorname{cov}\left(r_{i}, r_{j}\right)$

dengan kendala

$$
\begin{aligned}
\sum_{i=1}^{n} w_{i} & =1 \\
\sum_{i=1}^{n} w_{i} \cdot r_{i} & =r_{P} \\
w_{i} & \geq 0, \text { untuk } i=1 \text { sampai } n
\end{aligned}
$$

\section{Metode Penelitian}

Dalam penelitian ini data diperoleh dari website Bank Indonesia yaitu $\underline{w w w . b i . g o . i d}$ dan website yang menampilkan pergerakan saham-saham di Indonesia yaitu www.finance.yahoo.com yang mempublikasi data seluruh saham perusahaan yang aktif di Indonesia. Penelitian ini dilakukan selama satu bulan.

Jenis penelitian yang akan dilakukan dalam penelitian ini adalah studi kasus. Jenis data pada penelitian ini merupakan data sekunder yang diperoleh melalui studi kepustakaan, referensi berupa laporan yang dikeluarkan oleh Bank Indonesia, dan berbagai website yang menyediakan data-data yang dibutuhkan dalam penelitian ini seperti harga-harga saham yang diperoleh dari www.finance.yahoo.com.

Adapun langkah-langkah yang digunakan dalam penelitian ini adalah :

1. Mengumpulkan data harga saham penutupan bulanan masing-masing emiten periode Februari 2017 - Januari 2018. Data closing price dari tiap emiten kemudian digunakan untuk dicari return bulanannya. 
2. Berdasarkan data return bulanan dan rata-rata saham bulanan dari prosedur sebelumnya akan ditentukan varian dan standar deviasi dari saham-saham individual sebagai representasi risikonya.

3. Mengumpulkan data harga penutupan bulanan Indeks Harga Saham Gabungan (IHSG) periode penelitian. Data ini kemudian digunakan sebagai return portofolio pasar.

4. Berdasarkan data return pasar dari prosedur sebelumnya akan ditentukan expected return portofolio pasar. Expected return portofolio pasar adalah ratarata dari return portofolio pasar.

5. Selanjutnya akan ditentukan varian dan standar deviasi dari IHSG sebagai representasi risiko portofolio pasar.

6. Dari risiko saham-saham individual dan risiko pasar yang sudah ditentukan pada prosedur sebelumnya, kemudian ditentukan $\beta$ (beta) untuk masing-masing saham individual. 7.

7. Mengumpulkan data return aset bebas risiko periode penelitian kemudian dihitung rata-rata dan variansinya. Data return aset bebas risiko direpresentasikan oleh suku bunga Sertifikat Bank Indonesia (SBI) yang diperoleh dari www.bi.go.id.

8. Setelah diperoleh rata-rata data return aset bebas risiko (SBI), expected return portofolio pasar, dan $\beta$ masing-masing saham individual kemudian menentukan expected return CAPM dari masing-masing saham individual.

9. Prosedur selanjutnya adalah menyeleksi saham-saham individual dengan koefisien variasi dari masing-masing saham individual. Koefisien variasi ditentukan dengan standar deviasi dan return masing-masing saham individual.

10. Setelah menyeleksi saham-saham berdasarkan koefisien variasinya, kemudian ditentukan kovarian antarsaham yang dipilih. Kovarian antarsaham adalah salah satu input dalam fungsi objektif portofolio optimal Markowitz.

11. Setelah didapat lima saham unggul yang akan dibentuk ke dalam sebuah portofolio, kemudian ditentukan bobot masing-masing saham unggulan tanpa diversifikasi artinya $100 \%$ saham dibagi sama rata pada kelima saham. Setiap saham diberi bobot yang sama yaitu sebesar $20 \%$.

12. Menghitung expected return portofolio dengan mengalikan setiap bobot sahamsaham dengan return saham masing-masing kemudian dijumlahkan keseluruhannya. 
13. Menghitung risiko (varian dan standar deviasi) portofolio pada lembar kerja Excel dengan menggunakan rumus berikut pada sel varian.

14. Membentuk sebuah portofolio baru yang melalui proses optimalisasi. Langkah pertama adalah meminimumkan fungsi objektif portofolio optimal Markowitz dengan menggunakan software Microsoft Excel Solver add-ins.

15. Output dari proses optimalisasi portofolio dengan menggunakan software Microsoft Excel Solver add-ins adalah bobot kelima saham, expected return portofolio, dan risiko portofolio. Pada lembar kerja Excel digunakan rumus yang sama pada prosedur sebelumnya dalam menentukanexpected return dan risiko portofolio tanpa optimalisasi.

16. Menyajikan portofolio tanpa optimalisasi dan portofolio dengan optimalisasi pada sebuah tabel dengan menyertakan return dan risiko masing-masing portofolio.

17. Menarik kesimpulan dengan menyajikan data portofolio optimal dalam sebuah kurva normal yang menggambarkan luasan peluang terjadinya kerugian guna menyajikan data yang lebih mudah dipahami.

\section{Hasil Dan Pembahasan}

\subsection{Menghitung Return Saham Individual}

Dalam memilih saham undervalued, langkah pertama yang dilakukan adalah mencari nilai return 45 saham kemudian memilih saham dengan capital gain (return positif). Dari 45 saham aktif di LQ-45 pada periode penelitian, 32 di antaranta mengalami capital gain. Urutan saham-saham dengan return positif itu ditampilkan pada Tabel 1. 
Tabel 1: Tabel Saham-Saham dengan Return Positif

\begin{tabular}{|c|c|c|c|}
\hline No. & Saham & No. & Saham \\
\hline 1 & PTBA & 17 & JSMR \\
\hline 2 & BBRI & 18 & PWON \\
\hline 3 & BBTN & 19 & SRIL \\
\hline 4 & INCO & 20 & SMGR \\
\hline 5 & UNTR & 21 & CPIN \\
\hline 6 & BBCA & 22 & ASRI \\
\hline 7 & ADRO & 23 & ELSA \\
\hline 8 & BBNI & 24 & ADHI \\
\hline 9 & INTP & 25 & KLBF \\
\hline 10 & BMRI & 26 & ASII \\
\hline 11 & ANTM & 27 & TLKM \\
\hline 12 & UNVR & 28 & ICBP \\
\hline 13 & BUMI & 29 & BSDE \\
\hline 14 & GGRM & 30 & MNCN \\
\hline 15 & HMSP & 31 & EXCL \\
\hline 16 & WSKT & 32 & PGAS \\
\hline
\end{tabular}

\subsection{Menghitung Koefisien Beta Saham Individual}

Terdapat tiga klasifikasi koefisien beta saham, yaitu saham agresif $(\beta>1)$, saham pasar $(\beta=1)$, dan saham defensif $(\beta<1)$. Dalam penelitian ini dipilih saham-saham unggul dengan klasifikasi agresif. Sebanyak 12 saham dari 32 saham yang memiliki return positif merupakan saham dengan koefisien beta agresif. Tabel 2 menyajikan daftar saham dengan koefisien beta agresif.

Tabel 2: Tabel Saham-Saham dengan Koefisien Beta Agresif

\begin{tabular}{|c|c|c|}
\hline No. & Saham & Beta \\
\hline 1 & PGAS & 3.198 \\
\hline 2 & INTP & 2.824 \\
\hline 3 & ADRO & 2.349 \\
\hline 4 & CPIN & 2.006 \\
\hline 5 & WSKT & 1.819 \\
\hline 6 & HMSP & 1.508 \\
\hline 7 & SMGR & 1.448 \\
\hline 8 & PWON & 1.386 \\
\hline 9 & ADHI & 1.305 \\
\hline 10 & BBNI & 1.303 \\
\hline 11 & UNVR & 1.134 \\
\hline 12 & ANTM & 1.097 \\
\hline
\end{tabular}




\subsection{Menghitung Koefisien Variasi Saham-Saham Individual}

Setelah diperoleh dua belas saham dengan koefisien beta agresif, kemudian dihitung expected return $\left(E\left(r_{i}\right)\right)$ saham-saham tersebut lalu dibandingkan nilainya dengan return realisasi $\left(r_{i}\right)$. Apabila $E\left(r_{i}\right)$ bernilai lebih dari $r_{i}$ maka saham tersebut dikategorikan sebagai saham overvalued. Saham overvalued dari dua belas saham dengan koefisien beta agresif adalah saham ANTM dan ADHI. Selebihnya merupakan saham undervalued.

Sepuluh saham undervalued dihitung nilai koefisien variasi dengan membagi standar deviasi saham dengan returnnya. Hasilnya adalah seperti berikut :

Tabel 3: Tabel Nilai Koefisien Variasi Sepuluh Saham Terbaik

\begin{tabular}{|c|c|c|}
\hline No. & Saham & CV (\%) \\
\hline 1 & UNVR & 186.658 \\
\hline 2 & BBNI & 206.545 \\
\hline 3 & HMSP & 287.281 \\
\hline 4 & ADRO & 303.780 \\
\hline 5 & INTP & 324.132 \\
\hline 6 & PWON & 464.288 \\
\hline 7 & SMGR & 649.808 \\
\hline 8 & WSKT & 718.834 \\
\hline 9 & CPIN & 866.538 \\
\hline 10 & PGAS & 10780.689 \\
\hline
\end{tabular}

Dari Tabel 3 diperoleh lima saham terbaik yang akan dibentuk ke dalam sebuah portofolio adalah saham UNVR, BBNI, HMSP, ADRO, dan INTP.

\subsection{Grafik Closing Price Lima Saham}

\section{Saham UNVR}

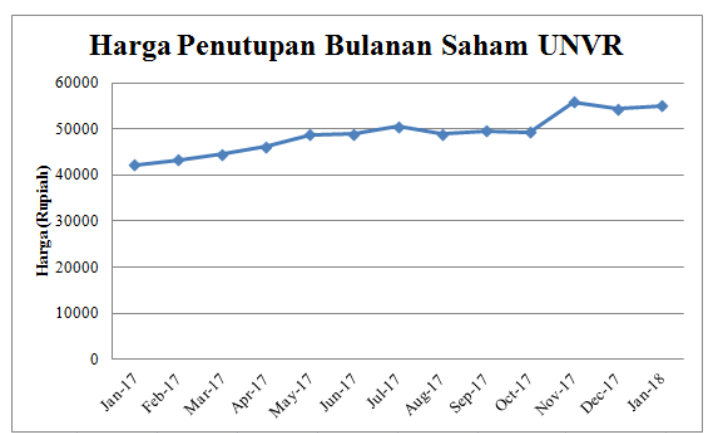




\section{Saham BBNI}

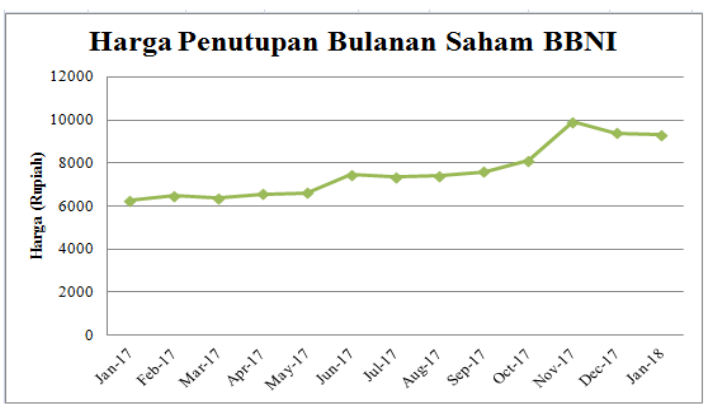

\section{Saham HMSP}
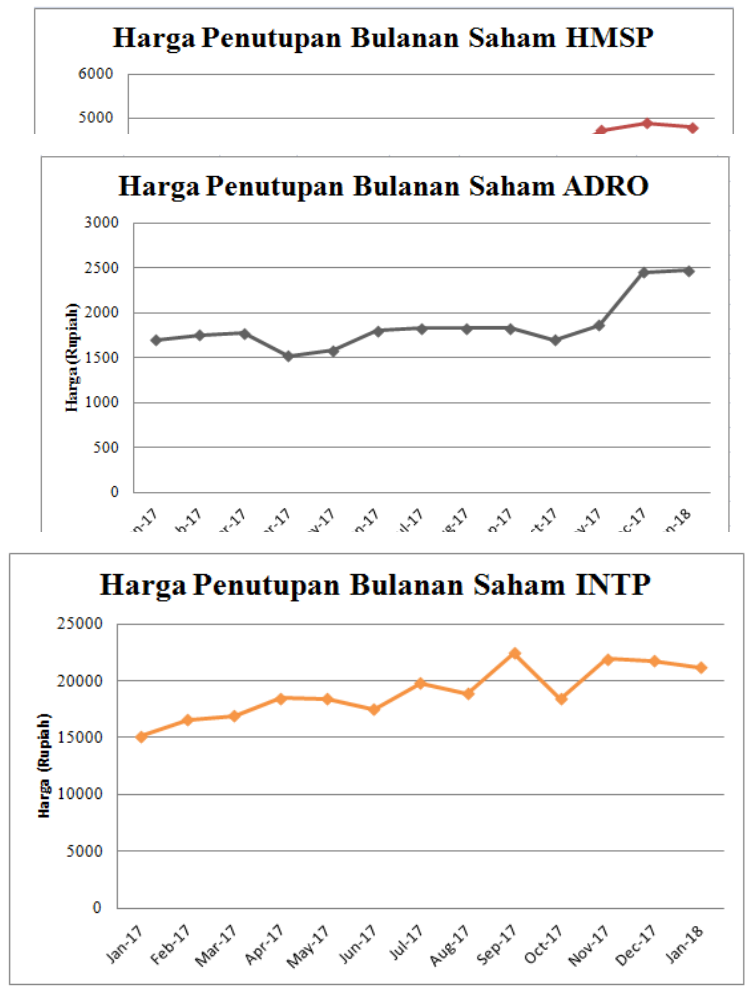

\subsection{Membentuk Portofolio Optimal}

Setelah diperoleh lima saham terbaik yang akan dibentuk ke dalam sebuah portofolio, kemudian dicari nilai varian-kovarian antarsaham. Nilai varian-kovarian antarsaham merupakan input dalam perhitungan mencari nilai optimal dari varian portofolio.

Dengan menggunakan Microsoft Excel Solver add-ins akan diminimalisasikan fungsi tujuan yaitu varian portofolio (atau standar deviasi portofolio) untuk memperoleh portofolio optimal dengan kombinasi terbaik antara return, risiko, dan bobot dari kelima saham. 
Pertama dibentuk sebuah saham tanpa optimalisasi seperti yang terlihat pada Tabel 4 berikut :

Tabel 4: Tabel Portofolio tanpa Optimalisasi

\begin{tabular}{|l|c|c|c|c|}
\hline Saham & $\boldsymbol{r}_{\boldsymbol{i}}$ & $\boldsymbol{w}_{\boldsymbol{i}}$ & PO.RET & PO.DEV \\
\cline { 1 - 2 } UNVR & 2.323 & 0.2 & & \\
\cline { 1 - 2 } BBNI & 3.598 & 0.2 & & \\
\cline { 1 - 3 } HMSP & 1.949 & 0.2 & \multirow{2}{*}{$2.9924 \%$} & $4.8042 \%$ \\
\cline { 1 - 3 } ADRO & 3.722 & 0.2 & & \\
\cline { 1 - 2 } INTP & 3.370 & 0.2 & & \\
\hline
\end{tabular}

Tabel 5: Tabel Portofolio dengan Optimalisasi

\begin{tabular}{|l|c|c|c|c|}
\hline Saham & $\boldsymbol{r}_{\boldsymbol{i}}$ & $\boldsymbol{w}_{\boldsymbol{i}}$ & PO.RET & PO.DEV \\
\cline { 1 - 3 } UNVR & 2.323 & 0.2 & & \\
\cline { 1 - 2 } BBNI & 3.598 & 0.2 & & \\
\cline { 1 - 3 } HMSP & 1.949 & 0.2 & \multirow{2}{*}{$2.4408 \%$} & $3.7072 \%$ \\
\cline { 1 - 2 } ADRO & 3.722 & 0.2 & & \\
\cline { 1 - 3 } INTP & 3.370 & 0.2 & & \\
\hline
\end{tabular}

\section{Kesimpulan Dan Saran}

\subsection{Kesimpulan}

Berdasarkan hasil penelitian dan pembahasan mengenai optimalisasi portofolio sahamsaham LQ-45 dengan menggunakan CAPM diperoleh beberapa kesimpulan sebagai berikut :

1. Sebanyak 45 saham di indeks liquiditas 45 (LQ-45) terdapat sepuluh saham efisien dan lima di antaranya dengan koefisien variasi positif terkecil yaitu saham Unilever Indonesia Tbk. (UNVR), Bank Negara Indonesia (Persero) Tbk. (BBNI), HM Sampoerna Tbk. (HMSP), Adaro Energy Tbk. (ADRO), dan Indocement Tunggal Prakasa Tbk. (INTP) dikombinasikan ke dalam sebuah portofolio yang akan dioptimalkan.

2. Secara ringkas hasil dari proses pemilihan saham undervalued adalah sebanyak 22 saham dari 45 saham di indeks liquiditas 45 (LQ-45) mengalami capital loss, 
11 saham di antara 23 saham yang mengalami capital gain merupakan saham dengan beta defensif, dan 2 saham dari 12 saham dengan beta agresif merupakan saham overvalued.

3. Dengan meminimukan fungsi objektif yaitu varian portofolio diperoleh bobot kelima saham adalah saham UNVR sebesar 65.4\%, saham HMSP sebesar 20.6\%, saham ADRO sebesar $14.0 \%$. Saham BBNI dan INTP menyumbang bobot sebesar $0.0 \%$ pada portofolio ini atau dengan kata lain tidak ada proporsi dana yang diinvestasikan pada kedua saham.

4. Dengan return dan risiko portofolio berturut-turut adalah $2.4408 \%$ dan $3.7072 \%$ dan dengan asumsi data penelitian berdistribusi normal, diperoleh perbandingan mengalami keuntungan dan kerugian adalah berturut-turut sebesar $75.46 \%$ : $24.54 \%$.

\subsection{Saran}

Dalam penelitian ini digunakan data return bulanan saham mulai Februari 2017 Januari 2018 dan data diolah menggunakan Microsoft Excel Solver add-ins. Penulis memberikan beberapa saran sebagai berikut :

1. Bagi peneliti, penulis menyarankan apabila akan membuat portofolio dengan CAPM juga sebaiknya menggunakan periode yang terkini dengan lebih banyak satuan waktu yang digunakan dan menggunakan software lain seperti MATLAB, LINDO, dan sebagainya.

2. Bagi investor,dalam penelitian ini saham-saham yang dikombinasikan ke dalam portofolio merupakan saham dengan rekam jejak performa yang baik (saham blue chip) di pasar modal Indonesia. Penulis menyarankan para investor pemula untuk selalu mempertimbangkan saham-saham blue chip selain mempertimbangkan returndan risiko yang ditawarkan.

\section{DAFTAR PUSTAKA}

[1] Halim, A. Analisis Investasi. Jakarta : Salemba Empat

[2] Hartono, J. 2008. Teori Portofolio dan Analisis Investasi. Yogyakarta : FE UGM

[3] Sartono. 2008. Manajemen Keuangan: Teori dan Aplikasi. Yogyakarta : BPFE Yogyakarta.

[4] Bodie, Zvi, dkk. 2011. Investment. New York: McGraw-Hill/Irwin 
[5] Fitriani, Ari. 2014. Optimalisasi Portofolio Saham dengan Menggunakan Model Markowitz.

[6] Hidayati, A. A, et al. Analisis Metode Capital Asset Pricing Model (CAPM) Terhadap Keputusan Investasi Saham. Vol. 9, No. 1

[7] Hadi, Nor. 2013. Pasar Modal. Yogyakarta : Graha Ilmu

[8] Rodoni, Ahmad dan Othman Yong. 2002. Analisis Investasi dan Teori Portofolio. Jakarta : PT Raja Grafindo Persada

[9] Focardi, Sergio M. dan Frank J. Fabozzi. 2014. The Mathematics of Financial Modelling and Investment Management. New Jersey: John Wiey And Sons Inc.

[10] Seftyanda, B. E, et al. 2014. Analisis Metode Capital Asset Pricing Model (CAPM) sebagai Dasar Pengambilan Keputusan Investasi Saham. Vol. 17, No.2 